\title{
A Case Report: \\ Clozapine in Diabetic Patient with Bipolar Mood Disorder
}

\author{
Vera, Christine Sitha \\ Department of Internal Medicine, Faculty of Medicine \\ Maranatha Christian University \\ Jl. Kopo 161 Bandung 40234 Indonesia \\ Email:drvr76@yahoo.com
}

\begin{abstract}
Depression and diabetes are often occur together and their morbidity has a significant impact of health outcomes. Antidepressants dan antipsychotics may cause metabolic abnormalities, as well as neurologic abnormalities. 52 years old diabetic woman presented to Immanuel Teaching Hospital with slurred speech. Since ten years ago, she had bipolar mood disorder, which was recently treated with clozapine. As patient consumed higher dose of clozapine (beyond her psychiatrist's supervision), she had uncontrolled blood glucose level, fever, and slurred speech. The side effects of clozapine (weight gain, increased insulin resistance, dysarthria, fever) were discussed in this case report. During hospitalization, with strict supervision of clozapine use, the symptoms resolved. In diabetic patients with comorbid psychiatric disorders, a good collaboration between internist and psychiatrist is required to manage the patients effectively and comprehensively.
\end{abstract}

Keywords: bipolar mood disorder, clozapine, diabetes mellitus, depression 


\title{
Laporan Kasus: \\ Clozapine pada Pasien Diabetes Melitus dengan Gangguan Bipolar
}

\author{
Vera, Christine Sitha \\ Bagian Ilmu Penyakit Dalam, Fakultas Kedokteran Universitas Kristen Maranatha/ \\ RS Immanuel \\ Jl. Kopo 161 Bandung 40234 Indonesia \\ Email:drvr76@yahoo.com
}

\begin{abstract}
Abstrak
Depresi dan diabetes melitus biasanya ditemukan bersamaan dan morbiditasnya mempunyai dampak terhadap kondisi kesehatan. Obat antidepresan dan antipsikotik dapat menyebabkan gangguan metabolisme dan gangguan neurologis. Seorang wanita 52 tahun datang ke RS Immanuel dengan keluhan bicara tidak jelas. Sejak 10 tahun yang lalu, pasien menderita gangguan bipolar, yang terakhir diobati dengan clozapine. Seiring dengan peningkatan dosis clozapine (di luar pengawasan psikiaternya), pasien mengalami peningkatan glukosa darah tak terkontrol, demam, dan bicara tak jelas. Efek samping clozapine (peningkatan berat badan, peningkatan resistensi insulin, dysarthria, demam) dibahas dalam laporan kasus ini. Selama opname, gejala mereda dengan pengawasan ketat penggunaan clozapine. Pada pasien diabetes melitus dengan gangguan psikiatrik sebagai komorbid, kerjasama yang baik antara dokter ahli penyakit dalam dan psikiater diperlukan agar dapat mengelola pasien secara efektif dan tuntas.
\end{abstract}

Kata kunci: clozapine, diabetes melitus, depresi, gangguan bipolar 


\section{Introduction}

Psychiatric comorbidity is common in patients with diabetes mellitus. Bipolar mood disorder in diabetic patientsis associated with impaired quality of life, increased cost of care, poor treatment adherence, poor blood glucose level/glycemic, and higher frequency of hospitalization. Weight gain and impaired glucose tolerance could emerge as side effects of the psychiatric medications. When treating bipolar mood disorder, the antipsychotic drug should be carefully chosen to avoid the aggravation of metabolic syndrome. Thus multidisciplinary collaboration between internist and psychiatrist is needed to ensure the effectiveness diabetes care in diabetic patients with bipolar mood disorder.

\section{Case Illustration}

Mrs. N, 52 years old woman, came to Immanuel Teaching Hospital with fever since two weeks prior to admission. Since ten years ago, she had bipolar mood disorders, which was recently treated with clozapine and alprazolam. She also had history of diabetes mellitus and hypertension since five years ago. She had her blood glucose checked every month at home. Her average blood glucose level was $200 \mathrm{mg} / \mathrm{dL}$, controlled by metformin and glibenclamide.

Since four weeks ago, her psychiatrist increased her clozapine dosage from $2 \times 25 \mathrm{mg}$ to $2 \times 50 \mathrm{mg}$. She gained more weight since then. Two weeks ago Mrs $\mathrm{N}$ had fever and increased frequency of urination. One week before admission, she complained slurred speech and low frequency tinnitus.

On physical examination, Mrs N showed dysarthria. Her BMI was 31,25. There was no other abnormalities. Due to high fever and high blood glucose level (500 mg/dL), Mrs $\mathrm{N}$ was hospitalized.

The psychiatrist tried to reduce the dosage of the clozapine since the first day of hospitalization, but the dysarthria persisted until the fourth day of hospitalization. On the fifth day of hospitalization, Mrs N's daughter reported a large amount of clozapine tablets (with different names at variable dose) in the patient's purse. Apparently, for the last four weeks, Mrs $\mathrm{N}$ had been taking clozapine as frequent as she wanted, beyond medical supervision, to maintain her "good mood".

The patient's blood glucose level decreased as soon as the clozapine use was closely monitored by her family and nurses. The blood glucose daily curve was depicted in the figure 1 . Her dysarthria also begin dismiss. Her fever, which was found due to urinary tract infection, also 


\section{Research Article}

responded well with intravenous antibiotics. Mrs $\mathrm{N}$ was discharged from the hospital on the seventh day.

\section{Discussion}

Type 2 diabetes mellitus rates are three times higher in patients with bipolar disorder, compared to the general population. Life-style and adverse effects of pharmacotherapy may be contributing factors for bipolar disorder patients to have diabetes mellitus. ${ }^{1}$ Diabetic patients with bipolar disorder have a more severe course of illness and are more refractory to treatment.

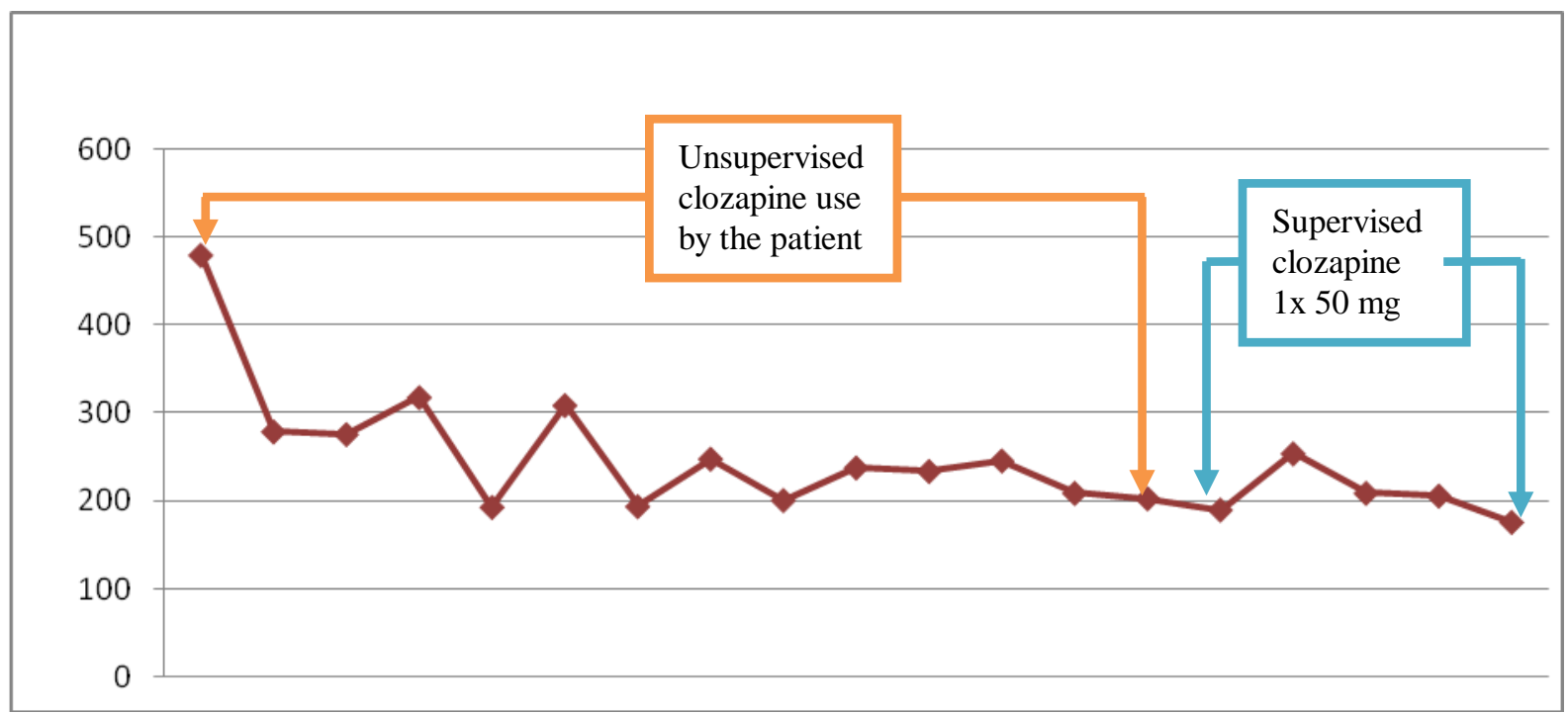

Figure 1 Daily Curve of Blood Glucose Level

Initially, clozapine was FDA-approved for the treatment of patients with schizophrenia, which is a type of medicine known as an atypical antipsychotic. Later on, clozapine was approved for bipolar disorder as well. Despite their lower propensity for extrapyramidal side effects, atypical antipsychotics have been associated with exacerbating metabolic disorders, such as obesity, diabetes, and dyslipidemia. ${ }^{2}$

In this patient, clozapine use induced weight gain. The mechanism of clozapine-related weight gain is unclear. The increased antagonistic affinity of clozapine for muscarinic and histaminergic receptors may be responsible for the increased weight gain. ${ }^{3}$ Kluge et al found that clozapine was associated with an increase in self-reported binge eating and a significant increase in food craving. ${ }^{4}$ However, the study was conducted on an inpatient population and there was no placebo control group so it is difficult to interpret whether the food craving was a function of the 


\section{Research Article}

limitations of a hospital diet or a direct consequence of the drug administration. Diet, exercise, and nutritional education are recommended to limit weight gain effectively.

Fever was reported in $4-13 \%$ of clozapine-treated patients. The peak incidence of the fever commonly occurs within the first three weeks of treatment. Clozapine-related fever is usually benign, transient, and responds to antipyretics. However, underlying infection and agranulocytosis must always be ruled out. ${ }^{5}$ Since a lot of white blood cells were found in Mrs N's urinalysis, urinary tract infection was considered to be responsible for the fever.

The glycemic control of Mrs $\mathrm{N}$ worsened since she started clozapine therapy. There are several case reports about clozapine administration resulting in exacerbations in diabetic patients. Mechanism of clozapine-induced hyperglycemia was depicted in the figure 2. In most patients, the hyperglycaemia occurred within six weeks after taking clozapine. In two patients, severe hyperglycaemia and ketoacidosis occurred within 1 week. $^{6}$

In fact, most cases of new-onset disturbances of the glucose homeostasis were reversible after discontinuation of clozapine. In this case, the psychiatrist and the patient's family were unaware that the patient taking clozapine several times a day to "improve" her mood. The exact dose of ingested clozapine was unknown, but it was surely more than the psychiatrist's prescribed dose. Her blood glucose level went down as soon as the family supervised the dose of clozapine she taken.

The dysarthria in this patient was thought due to clozapine's side effects, because there was no other neurologic abnormalities suggesting vertebrobasillar stroke (facial numbness, facial weakness, vertigo, dysphagia, ataxia) and the symptom disappeared along with the reduce dosage of clozapine. However, the neurologist ordered head MRI to exclude acute stroke, considering she had several cardiovascular risk factors (obesity, diabetes mellitus, hypertension, dyslipidemia). Clozapine is associated with diffuse slowing and increased paroxysmal activity on EEG pattern. Two patients suffered tonic-clonic seizures while on clozapine and in these patients co-prescription of an anticonvulsant (sodium valproate) abolished the stuttering. Patients with either a family or personal history of stuttering might be vulnerable to the side effect of clozapine, especially dysarthria. ${ }^{7}$ 


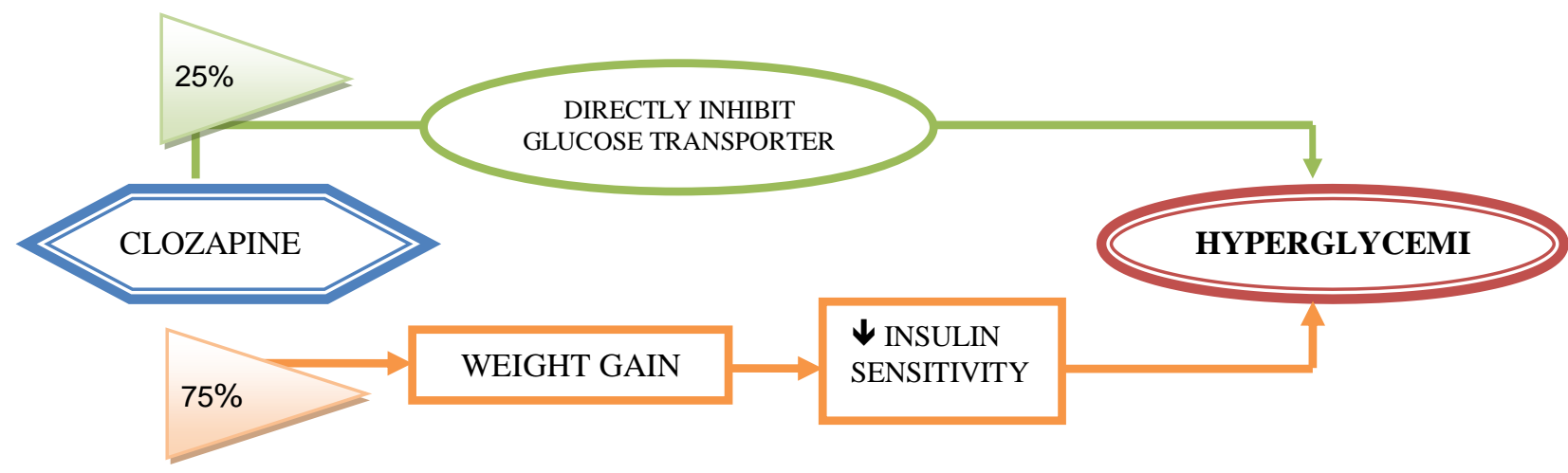

Figure 2 Mechanism of Clozapine-induced Hyperglycemia

\section{Conclusion}

Considering various side effects of clozapine (weight gain, fever, hyperglycemia, dysarthria), clozapine should be used caustiously in diabetic patients with bipolar mood disorder. A good collaboration between internist and psychiatrist is needed to ensure good quality of life in diabetic patients with bipolar mood disorder.

\section{Reference}

1. Calkin CV, Gardner DM, Ransom T, Alda M. The relationship between bipolar disorder and type 2 diabetes: more than just co-morbid disorders. Ann Med. 2013;45(2):171-81.

2. Davis JM, Chen N. Old versus new: weighing the evidence between the first- and second-generation antipsychotics. Eur Psychiatry. 2005;20:7-14.

3. Teff KL, Kim SF. Atypical antipsychotics and the neural regulation of food intakeand peripheral metabolism. PhysiolBehav. 2011;104(4): 590-8.

4. Kluge M, Schuld A, Himmerich H, Dalal M, Schacht A, et al. Clozapine and olanzapine areassociated with food craving and binge eating: results from a randomized double-blind study. J Clin Psychopharmacol. 2007; 27(6):662-6.

5. Miller DD. Review and management of clozapine side effects. J Clin Psychiatry 2000; 61(suppl8):14-17.

6. Tschoner A, Laimer JEM, Kaser S, Rettenbacher W, Fleischhacker W, Patsch JR, Ebenbichler CF. Metabolic side effects of antipsychotic medication. Int J ClinPract. 2007;61(8):1356-70.

7. Lyall M, Pryor A, Murray K. Clozapine and speech dysfluency: two case reports. Psychiatric Bulletin 2007; 31:16-8. 